\title{
Prison without Walls: Perception about Community Service as an Alternative to Imprisonment in Kumasi Metropolis, Ashanti Region, Ghana
}

\author{
Kwadwo Ofori-Dua ${ }^{1}$, Kofi Osei Akuoko ${ }^{1}$, Jonas Asamanin Barnie ${ }^{1}$, John Yaw Kwarteng ${ }^{1}$ \& John Boulard Forkuo ${ }^{1}$ \\ ${ }^{1}$ Department of Sociology and Social Work, Faculty of Social Sciences, College of Humanities and Social Sciences, \\ Kwame Nkrumah University of Science and Technology, Kumasi, Ghana. \\ Correspondence: Kofi Osei Akuoko, Department of Sociology and Social Work, Faculty of Social Sciences, College of \\ Humanities and Social Sciences, Kwame Nkrumah University of Science and Technology, Kumasi, Ghana.
}

Received: September 1, 2015

Accepted: September 24, 2015

Available online: October 15, 2015

doi:10.11114/ijsss.v3i6.1143

URL: http://dx.doi.org/10.11114/ijsss.v3i6.1143

\begin{abstract}
The numerous challenges, such as increasing prisoner population, inadequate financial support and deteriorated training facilities, have not enabled the Prisons Service to perform their functions adequately. The paper aimed at investigating the perception among residents of Kumasi metropolis about community service as an alternative to imprisonment. This study adopted the social survey research design to investigate the perception of 200 respondents regarding community service as an alternative form of punishment to imprisonment. The study revealed that generally, the public were well informed about community service and preferred it to imprisonment. On the contrary, preference for community service was related to its perceived appropriateness for reducing the stigma that was usually attached to ex-convicts as well as its perceived ability to reform offenders better than imprisonment. Respondents agreed that minor offences were appropriate for community sentences. Also, people with communicable diseases, pregnant and nursing mothers, single parents and first time offenders should be given community service which must be communal in nature. Some recommendations were made.
\end{abstract}

Keywords: Community service, Public perception, Imprisonment, Punishment, Offenders, Criminal justice.

\section{Introduction}

Ideally, prisons are to provide safe, secure and humane containment for convicted offenders who pose potential threat to the security and safety of the community. They aim at reforming the prisoners to be able to fit into the society when they eventually return into it. However, the Ghana Prison Service, due to numerous challenges, such as increasing prisoner population, inadequate financial support, deteriorated training facilities among others, (Ghana Prison Service, 2009, 2010), have not been able to perform this function adequately.

History has it that the Penal system in the Gold Coast started in an irregular manner from the early 1800 s under the chairmanship of Captain George Maclean. By 1841, a form of prison had been established in the Cape Coast Castle where debtors, possibly, were incarcerated. From 1875, it was extended to the entire southern part of present day Ghana and in 1876; the Gold Coast Prison Ordinance was introduced. By 1880, caretakers were introduced but due to unsatisfactory services, the Prisons Department was placed under the Police Administration and later separated in 1920 due to an increase in Prison Establishment and staff. By 1948, there were twenty-nine (29) Establishments all over the country. On 1st January, 1964, the Prisons Department became autonomous and was renamed Ghana Prisons Service. In general, prisons are classified under three main security categories namely; Maximum, Medium and Minimum. However, due to inadequate facilities, prisons in Ghana are classified based on activities undertaken at the various prison establishments. The Prisons Service encompasses forty-five (45) Prison Establishments in all the ten regions of Ghana with the Prisons Headquarters located in Accra. In addition, there are seven (7) Central Prisons, seven (7) Female Prisons, fourteen (14) Local Prisons, one Medium Security Prison at Nsawam, one Contagious Disease Prison (CDP) at Ankaful and nine (9) Agricultural Settlement Camp prisons. A new Maximum Security Prison has been opened at Ankaful in the Central Region (www.ghanaprisons.gov.gh; accessed 20/08/15).

Increasing prisoner population limits the Prisons Service's ability to provide safe and humane custody for prisoners due 
to inadequate space in the various prison centres. The prisoner population in Ghana continues to grow at a rate of about $5 \%$ annually (Ghana Prison Service, 2008) resulting in over-crowding and its accompanying problems. This means that inmates are forced to share spaces meant for few people.

The Ghana Prisons Service Annual Report (Ghana Prisons Service, 2011) revealed a high incidence of re-offending among convicts and thus contributes significantly to the increasing prisoner population. Of the 7,011 convicts admitted in 2011,413 had been in prison before. One major effect of this over-crowding is the spread of diseases among inmates leading to high incidence of death. In 2011 for instance, total death of prisoners increased from the 2010 figure of 78 to 82 of which infectious/transferable diseases such as tuberculosis and malaria and others accounted for 33 deaths (Ghana Prisons Service, 2011). Another constraint on the Prisons Services' ability to reform inmates is inadequate financial resources. Total budgetary allocations to the Service continue to dwindle since 2008.

Even though the money might not be enough to ensure improved skill acquisition training programs for inmates, the fact remains that huge sums of money are spent on maintaining prisoners. Such amount of money could be spent on developmental projects or used to improve upon the welfare of the citizens. For instance, a total of Two Million, Three Hundred and Twenty-Seven Thousand, Five Hundred and Thirty-Five Ghana Cedis (GHC 2,327,035) was spent on prisoners ration alone in 2009 (Ghana Prisons Service, 2009). What makes the situation more perturbing is the fact that majority of the prisoner population is in the economically active age group (18 and 45) whose labour resource could be utilized in developing the country instead of draining the few available human resources.

Deteriorating training facilities in the prison centres also hamper the institution's ability to embark on effective skill acquisition training for the inmates. Most convicts enter the prisons with no meaningful skill to earn a decent living in the society. This assertion is made evident by the fact that offences such as stealing, robbery, and dishonest receiving dominate the crime index (Ghana Prison Service, 2007). This means that it is possible that if most people were equipped with skill to earn a decent living, they would not engage in such crime.

Undoubtedly, such concerns are shared by stakeholders in the correctional system of Ghana. It is for these reasons that a research into the public's perception about community service as an alternative to imprisonment is considered worthwhile.

Countries like Uganda, Burkina-Faso and Zimbabwe where community service scheme has been practiced efficiently continue to enjoy reduced prisoner population and reduced cost as well as accelerated development in the communities where it is practised (Masamba, 2002).

\subsection{Statement of the problem}

The Ghana Prisons Service was established to keep convicted offenders from the law abiding members of the society and to try and reform them to become useful to the society after serving their sentences. In Ghana, however, it appears the existence of prisons has not deterred potential criminals as crimes are constantly being committed and the more people are put in prison, the more crimes are committed. For example, the cumulative prison population in Ghana increased from four million, eight hundred and sixty-seven thousand, three hundred and sixty-six $(4,867,366)$ in 2007 to five million, one hundred and seventy thousand, eight hundred and forty $(5,170,840)$ in 2008 (2008 Annual Report of the Ghana Prisons Service). Of particular interest is the fact that official crime rate does not actually reflect the actual number of crimes committed in the society due to under-reporting because of, perhaps, lack of confidence in the law enforcement agencies. This means that actual crimes committed could be more than what the official figures show. Why has the thought of going to prison not scared people from committing crimes? Is there any correlation between imprisonment and crime reduction? Should reform efforts of Ghana be aimed solely at improving prison infrastructure?

Agboka (2008), has argued that if incarceration becomes so prevalent, it loses its stigma, its mystery and therefore some of its deterring power. The tougher prison conditions, the tougher criminals will become. How true can this be said about the rate of incarceration in Ghana and the subsequent rise in crime? Has the prison system been successful in controlling offenders and changing their behaviour? Will people be more willing to report crime if convicted criminals were punished for them to see? The harsh and peculiar living conditions in the prisons contribute greatly in helping to socialise the inmates to uphold deviant subculture to be able to survive in that environment.

According to the Ghana Prisons Service Annual Report for 2008, 1,806 out of 9,377 convicts in 2008 had served a prison term before. This raises several questions as to the effectiveness of the rehabilitation efforts of the Ghana Prisons Service. If more ex-convicts are returning to prison, then what could possibly be wrong? Is it not time for Ghana, as a society, to think of alternative means of punishing offenders which can also help to reform them instead of sending them back to prison to master their trade? This paper sought to examine the perception of residents in Kumasi metropolis about community service as an alternative to imprisonment. 


\subsection{Objectives of the study}

The main objective of the paper was to evaluate the perception of people in Kumasi metropolis about community service as an alternative to imprisonment. Specifically, the study sought to investigate the public's perception about community service as an alternative to imprisonment for victims of minor offences, identify activities to be performed under community service and find out the criteria to be used in selecting people for community service for effective implementation.

\subsection{Literature Review}

Community service is a punishment option which allows a convict to continue to stay at his place of residence and perform any work of communal benefit as a punishment instead of being confined to prison. The person receives no pay and works for a specified number of hours (Morris \& Tonry, 1990). It is a scheme in which carefully selected persons who have committed non-serious criminal offences like petty theft or causing minor damage to property are made to perform unpaid work of benefit to the community (Zedriga, 1998). Birungi (2005) sees community service as an optional alternative to imprisonment, in which the offender undertakes to perform free work that is beneficial to the community instead of going to prison. Community service therefore serves as alternative to prison in sanctioning offenders. With community service, the convict performs unpaid work to the benefit of the community. The decision to do community service varies from one country to the other. Whereas some countries make it optional, others make it obligatory, with respect to some offences (Zedriga, 1998). This study therefore sought to determine whether the public would prefer community service to be optional or not.

Community service comprises a mix of three interrelated activities which are supervision, programming and community involvement. Supervision is the direct monitoring of and communication with offenders (Künnapas, 2005). It is carried out by Criminal Justice staff known as parole officers or by trained volunteers, depending on the offender involved. All offenders on conditional release are supervised no matter where they live. The degree of supervision required will, however, depend on the individual offender. Offenders considered dangerous will require closer monitoring and more frequent contacts. Those who are considered to be of low risk, require less supervision. Parole officers rely on an array of information sources such as police, families, programme staff and others. By being aware of the offender's situation, staff can help ensure that he/she stays on track. They can take action when the offender breaks rules, or help solve problems that could lead to a crime 'relapse'. In Ghana, assembly members, family heads and members of the traditional council can be used to supervise offenders if community service was introduced. The nature of their involvement is, however, not within the scope of this study. Research, however, shows that supervision alone does not help offenders to change. Supervision along with good reformation programme does (Künnapas, 2005).

Community involvement is essential to successful supervision and programming in community sentences (Künnapas, 2005). This is because community contacts are a good source of important information on offenders and that helps the supervision process. Community punishments generally involve a number of punishment options or programmes which are aimed at reforming the offender by engaging him/her in an activity. They usually give greater freedom of movement rather than confinement to a prison facility. In the United Kingdom, it usually includes community rehabilitation, community punishment/service, community punishment and rehabilitation, electronic monitoring or tagging and drug treatment and testing (National Probation Service Report - NPS, 2002).In community rehabilitation centres, offenders are placed under supervision of a probation officer for the duration of the sentence, usually between six months and three years (NPS, 2002). With community service, offenders do unpaid work that benefits the community. This must be done at a rate of between five and 21 hours a week. The work must be physically, emotionally or intellectually demanding. This study therefore seeks to identify specific types of jobs offenders can be made to perform in Ghana.

Electronic monitoring or tagging is also referred to as curfew orders. An electronic tag is worn on the ankle of offenders placed under a form of 'house arrest' to monitor their movements. It is mostly done on offenders released early from prison or with restriction on their movement as in Scotland (NPS, 2000). The electronic tag sends regular signals through a phone line to a control centre. If the offender goes beyond the permissible boundary or breaks the curfew the control centre is immediately alerted for an appropriate action to be taken accordingly. The curfew order lasts up to six months, and the court specifies which hours the offender has to be at home, which can be between two and 12 hours a day. Drug treatment is targeted at people who commit crime to fund their drugs habit. Regular tests are conducted to prove that the offender is not violating the order or is responding to the treatment.

It is argued that the only guarantee for protecting the community from an offender during the period of a sentence is a custodial sentence. It has been calculated that over a quarter of offenders serving community sentences will have re-offended at least once by the time an offender has served an average length sentence (NPS, 2002). To most people, offenders who present a risk of serious harm to the community deserve custodial sentence. However, it needs to be noted that prison provides absolute protection from an individual only when he/she is in prison. Imprisonment therefore does 
not always mean protection from crime. Most people return to crime after serving their prison term. If prison has not done anything to change offending behaviour, it cannot be said in the long term, to protect the public. If community sentences are effective at reforming offenders, they are more likely to offer the most effective long-term protection of the public. Some community sentences offer more intensive supervision than others. The community surveillance element of the programme aims to ensure that both the offender and the community know that their behaviour is being monitored (NPS, 2002).

It is worth cautioning that as convincing as the argument of community service's ability to reform offenders sound, one must not lose sight of the fact that the offender was living in the society before becoming a criminal. If he/she could remain law abiding by living with law abiding people, he would not have become a criminal in the first place. How then, for instance, do we handle offenders who commit another crime whilst doing community service? This is one of the questions that this study seeks to answer.

According to the United Kingdom Home Office, there is no discernible difference between reconviction rates for custody and community penalties (NPS, 2002). According to the NPS report, 56\% of prisoners discharged from prison and commencing community penalties in 1995 were reconvicted within two years. Reconviction rates did vary by type of order however. Reconviction rates for prisoners released after short sentences of up to 12 months were higher $(60 \%)$ than those for longer term prisoners. It is possible that actual re-offending may be higher than that which is measured by reconviction rates. Crude measures of reconviction do not allow distinctions to be made between the seriousness of types of offence. It is a common knowledge that offenders with no reliable and legitimate source of income, place of residence and or have addiction problems are more likely to return to crime after their release. The social factors that affect the likelihood of re-offending include social rejection of the ex-convict by the people in the community to which he/she returns to.

Deterrence, rehabilitation, incapacitation and reformation are all aspects of the objective for punishing criminal offences. Windzio (2006), arguing from a deterrence perspective maintains that community service achieves less on reformation and therefore results in higher crime rates than imprisonment. He argues that within the deterrence framework the major aim of punishment is to discourage offenders and would-be offenders from committing future crimes. Thus, he argues that since the 'pains of imprisonment' are more severe than the 'pains' of community service (Windzio, 2006), the deterrent effect of community service is less strong than that of imprisonment.

However, several theories support the benefits of community service over imprisonment in reforming offenders. Differential association and learning theories under the Social-Process Approach, for instance, assume that criminal behaviour is learned through interaction and communication processes with other deviants (Akers, 1997). From this perspective, prisons are seen as 'schools of crime' where offenders meet one another and learn deviant attitudes and criminal behaviour. Thus, community service is thought to rehabilitate offenders partly through contacts with conventional co-workers (Harris \& Lo, 2002). This means that with reformation, community service performs better than imprisonment.

Similar to the learning theories, control theories state that individuals have a natural tendency toward crime, and that bonds to conventional society can restrain them from committing criminal activities (Hirschi, 1969; Sampson \& Laub, 1995). Differences in committing criminal activities exist through variation to the extent that people who believe in societal norms, are attached to non-deviant others, and are involved and committed to conventional activities (Sampson \& Laub, 1995). In the same vein, community service is intended to maintain or even strengthen these bonds (Bazemore \& Maloney, 1994).

Labeling theory suggests that official interventions contribute to the development of a criminal career rather than prevent offenders from living a life of crime (Becker, 1963; Bernburg \& Krohn, 2003). Deviant label and official labeling in particular can lead to economic and social stigmatization (Pettit \& Western, 2004), increasingly block opportunities for a conventional life (Becker, 1963; Farrington, 1977; Bernburg \& Krohn, 2003), and progressively isolate offenders from the law abiding community thus fostering their return to committing criminal activities (McAlinden, 2005).

According to retributive theory, punishment is justified because it assumes that the offender is treated in the same way he or she deserves to be punished. The community and the victim are more interested in seeing the offender serve a punishment for the crime he/she has committed. Since imprisonment is viewed negatively in the community, it is seen as providing the most suitable form of revenge for committing offence. By imprisoning the offender, society believes that the injustice that had been brought about by the crime committed is removed. As Gardiner in Rabie (1977) stated: "the desire to make the offender suffer, is not because it is good for him/her, nor suffering might deter him from further crime but simply because it is felt that he/she deserves to suffer and the suffering is thus the essence of retribution". Since the stigma attached to community service is not as degrading as that of imprisonment, community service is 
viewed as lenient and does not provide a suitable form of revenge to the victim. It is feared that people would be in danger of moral deterioration if those who commit crimes were left unpunished by the law or treated with leniency.

Pollick (2013), attempting to explain what constitutes public perception in an article dubbed, "what is public perception?" described it as a social phenomenon and defined it as the "difference between an absolute truth based on facts and a virtual truth shaped by popular opinion, media coverage and/or reputation". Thus, public perception influences or helps to shape the behaviour or conduct of celebrities, politicians and corporations by being conscious about the kind of perception that the public have about them. He indicated that perception can be either negative or positive and very difficult to change, especially a negative one. He insists that public perception is not necessarily always entirely inaccurate or based on something other than the truth. It is worthy to note that public perception of a given situation can be unrealistically positive or negative, which can become problematic whenever the true facts emerge and corrective action must be taken (Pollick, 2013). This explains the reason why many people feel very disturbed when a perceived good person is accused of a crime or a perceived bad industry is not penalized for its actions. Thus, the study would determine whether or not the people in Kumasi have sufficient knowledge about community service to enable them to assess the credibility of choices they make between community service and imprisonment. In an article about what the public thinks about sentencing, Velazquez and Co (2009), noted that studies gauging public perceptions about sentencing are predominantly based on sentencing in Canada, the UK and the USA, and a few about Australia. To them, studies about public perception are important because public attitudes to sentencing have a potential to influence the development of policies in any criminal justice system. They noted also that public confidence is essential for the effective functioning of justice by influencing the types of punishments meted out. In effect, assessing public opinion in the justice system is relevant because it is both a reflection of, and a potential influence over sentencing practices.

Given the assertion by Velazquez et al., it is important to compare the preference patterns for males and females in Kumasi, with respect to community service and imprisonment and identify what influences them.

\subsection{Conceptual Framework}

The process of becoming a recidivist is better fuelled by imprisonment than community service does due to the high degree of stigmatization and social rejection attached to imprisonment. Community service helps to pull offenders from this menace of stigmatization and social rejection of the offender after the sentence. Offenders who go through community service programmes are therefore able to reintegrate into the society after the sentence making them less likely to return to crime as compared to prisoners.

\section{Area of study}

The study area includes all areas administered by the Kumasi Metropolitan Assembly (KMA). The Kumasi Metropolis has three adult prison facilities consisting of two male prisons at Manhyia and Adum and a female prison facility at Adum (Kumasi Central Prison and Manhyia Prison). The three facilities accommodate several hundreds of convicts who might have developed some perceptions about imprisonment and its alternatives. In the same vein, the long existence of the prisons in the Metropolis might have caused residents to develop some perceptions about not only the convicts and imprisonment but alternatives to imprisonment as well. Such unique experiences of convicts and residents were considered valuable resources for this study. Also Kumasi being the second largest city in Ghana attracts several millions of people with varied degree of knowledge, skill and interest in social issues including human rights advocacy. The study therefore benefited from the rich and diverse experience of such people who would have been rare to come by in other parts of the Ashanti region of Ghana.

Kumasi is located in the transitional forest zone and is about $270 \mathrm{~km}$ north of the national capital, Accra and has a total surface area of $254 \mathrm{sq} \mathrm{km} \mathrm{(2000} \mathrm{population} \mathrm{census)} \mathrm{with} \mathrm{a} \mathrm{population} \mathrm{density} \mathrm{of} \mathrm{9434persons} \mathrm{per} \mathrm{sq.} \mathrm{km}$. It is between latitude $6.35^{\circ}-6.40^{\circ}$ and longitude $1.30^{\circ}-1.35^{\circ}$, an elevation which ranges between $250-300$ metres above sea level. The land area of the Metropolis is about $254 \mathrm{sq} / \mathrm{km}$ and approximately ten (10) kilometers in radius. There are 119 communities. In terms of demography, the Kumasi Metropolis is the most populous district in the Ashanti Region. It has a Population of 2,035,064 (2010 census) with an annual growth rate of 4.8\%. In 2013, the population of Kumasi was estimated at 2,396,458. Majority of the population (52.7\%) is below 15 years while the remaining $47.3 \%$ is above 15 years. The metropolis is divided into 10 sub-metros, namely Asokwa, Asawase, Bantama, Suame, Manhyia, Oforikrom, Tafo, Nhyiaeso, Subin and Kwadaso. The unique centrality of the city as a traversing point from all parts of the country makes it a special place for many to migrate to.

The metropolitan area shares boundaries with Kwabre East District to the north, Atwima District to the west, Ejisu-Juaben Municipal to the east and Bosomtwe to the south (GSS, 2010). 


\section{Research Methods}

\subsection{Research Design}

The research design chosen for this study was the social survey. A social survey is a process whereby information is collected about the social aspects of a community's composition and its activities. Questionnaires were used as the main tool for collecting data about the perceptions that people have about community service as an alternative to imprisonment in Ghana.

\subsection{Target Population}

Members of the general public resident in the Kumasi metropolis and the prison inmates of the three prison facilities in Kumasi metropolis constituted the population for the study.

\subsection{Study Population}

The study population was the residents in Bantama, Nhyiaeso, Kwadaso, Asokwa, Manhyia and Oforikrom who were of sound mind, aged eighteen years and above and were willing to participate in the study. In the case of the prisoners, the study population was convicts serving a prison term for minor offence and willing to respond to the questionnaire. The study population thus, comprised two categories of people: prisoners and the general public. The paper was limited to the residents in the six sub-metropolitan areas because it was impossible for the authors to reach out to all the residents in the ten sub-metropolitan areas.

\subsection{Sampling Units}

The sampling units for this study constituted prison inmates of the three prison facilities (Central Prisons, Manhyia Prisons and Female Prisons) and residents of the selected sub-metropolitan areas. Unfortunately, no such list could be obtained for either of the two categories of respondents. In the case of the general public there was no comprehensive statistical data base compiled by the metropolitan authorities with regard to nominal roll of the residents. The nominal roll of the prisoner population was classified and therefore could not be released to the authors. However, a sampling frame was constructed for the minor offenders based on their willingness to partake in the study. Those who were willing to answer the questionnaires and were minor offenders were enumerated from each prison to constitute the sampling frame for each prison. Respondents from the general public were purposefully selected to include people with diverse social, economic and demographic background such as students, legal practitioners, social workers, civil rights advocates and security services personnel.

\subsection{Sample Selection}

According to Neuman (2000), the question of sample size can be addressed in two ways. One is to make assumptions about the population and use statistical equations about random sampling processes. Here the researcher must make assumptions about the degree of confidence and the degree of variation in the population. By fixed statistical calculations, the size of sample required can be determined. The other option is the use of rule of thumb. One principle with the rule is that the smaller the population size, the bigger the sampling ratio and vice versa (Neuman, 2000). This is because as the population size grows the returns in accuracy for sample size shrinks. In this study the rule of thumb option was adopted in deciding on the sample size. As the population of study was large and all the elements in it could not be chosen for the study, a sample size of 200 people was selected. This was made up of 150 people from the general public and 50 prisoners.

\subsection{Sampling Technique}

The study relied on both probability and non-probability sampling techniques. The non-probability techniques used were quota, accidental and purposive sampling. The probability technique used was the simple random sampling by the lottery method of sampling without replacement. This was used to sample the six sub-metropolitan areas.

A combination of non-probability and probability techniques of sampling were used to select a total of 50 respondents from the three prison facilities in Kumasi. Each of the three prison facilities in Kumasi was given a proportional quota based on the estimated population at the time of collecting data. A quota in the ratio of 5:4:1 for Central Male, Manhyia and Central Female respectively, was given to each of the prison facility. In effect 25, 20 and 5 samples were taken from Central, Manhyia and Female Prisons respectively. The simple random sampling technique was then employed to select the required quota from each prison for the study. This was based on the constructed sampling frame for convicts serving minor offences in each prison who were willing to answer the questionnaires.

The accidental and purposive sampling technique was employed to select 150 respondents from the general public resident in the six sampled sub-metropolitan areas of Kumasi. The sub-metropolitan areas were Bantama, Nhyiaeso, Kwadaso, Asokwa, Manhyia and Oforikrom. Within each selected sub-metropolitan area, the authors either placed themselves at some strategic positions where they easily had access to the units of the population as they moved past 
them or visited locations where specific people could be accessed. Twenty-five (25) respondents were selected from each of the six sub-metropolitan areas to respond to the questionnaire, totaling 150 respondents. As noted by Flick (1998), it was their relevance to the research topic and convenience rather than their representativeness that determined the way in which the people were selected. Selection was based on the authors' discretion, initial interaction with prospective respondents and the willingness on the part of the persons approached to participate in the study.

\subsection{Methods of Data Collection}

The study made use of data from both primary and secondary sources. Textbooks, articles from journals, electronic information and Ghana Prisons Annual Report from 2007 to 2011 were accessed and used for the study as secondary data.

Questionnaire was the main tool for collecting primary data. The questionnaires were mostly self-administered but where respondents could not read and write or needed some further explanations, the authors read and explained the questions to them and recorded the respondents' answers accordingly. The questionnaire was used because it enabled the authors to reach many respondents within a short period of time at less cost. The questions were mostly close-ended and therefore made the coding relatively easier. Before any respondent answered the questions, the authors informed them that their participation was voluntary and that no incentive would be provided for participating in the study.

\subsection{Tools for Data Analysis and Presentation}

The Statistical Package for Social Sciences (SPSS) was the main tool for the analysis. The raw data collected from the field were coded into the SPSS package from which frequencies, proportions and percentages were derived. Statistical analytical tools of percentages and proportions were used to provide a more comprehensible presentation of the results from the data analysis for easy interpretation.

\subsection{Field Problems Encountered}

The Prisons Service is a security institution and as it is with all security agencies in Ghana, collecting information had to be done with some circumspection. Access to data on some administrative matters of the institution was a difficult task. In addition, much of the information bothering on security and safety of inmates was censored and would not be allowed in the public domain. In particular, the restriction on access to nominal roll of inmates hindered the proper use of probabilistic sampling method to select samples for the study. Several inmates had to be interviewed first before applying the lottery method to select some of them to answer the questionnaires for the study. This therefore militated against the representativeness of the sample from which data were collected. The unwillingness to respond to the questionnaire on the part of some members of the general public also made collection of data difficult. The general applicability of the findings of this study was thus limited.

\section{Results}

\subsection{Socio-Demographic Characteristics of Prison Respondents}

\subsubsection{Sex of Respondents}

$90 \%$ of the prisoners selected for the study were males and $10 \%$ were females. This explained the common knowledge that men were more prone to committing crimes than women. With men being the breadwinners in most families, their incarceration affected the family members, particularly children, to the extent that some ended up becoming deviants, with its attendant problems to the society. The sex distribution of the respondents did not mirror that of the society. Even though women outnumber men in the society, more men accepted to respond to the questionnaire than the women. This was an indication that men dominated the female population in terms of participation in the discussions about issues of national importance. $56.7 \%$ of the general public was males and $43.3 \%$ was females. According to the official website of the Ghana Prisons Service, there are 11,288 male convicted prisoners and 155 female convicted prisoners representing $83 \%$ of total inmate population. For unconvicted prisoners, there are 2,369 males and 43 females representing $17 \%$ of total inmate population. Therefore the total number of male inmates is 13,657 (98.61\% of the total inmate population whiles the total number of female inmates is 198 (1.39\% of the total inmate population).

\subsubsection{Age of Respondents}

The data revealed that the prison population was significantly people of the active working age group. About $98 \%$ of the respondents were aged between 18 and 41 years and the distribution reflected that of the prison population in general. Thirty percent (30\%) was aged between $18-25$ years, $48 \%$ was between $26-33$ years, $20 \%$ was between $34-41$ years and $2 \%$ were between $42-49$ years. The data depicted that Ghana was denying itself of the contribution of able-bodied men who could contribute to the Gross Domestic Product (GDP). The study benefitted from the views of people in the active working age group as anticipated. About two-thirds of the respondents were aged between 18 and 41 years. Given that this age bracket dominated the age distribution of the study area, it presupposed that if policies were enacted based 
on their views there would be a general support for the policies' implementation $(31.4 \%$ were aged between $18-25$ years, $34 \%$ were between 26 - 33 years, $15.3 \%$ were between $34-41$ years, $11.3 \%$ were between 42 - 49 years and $8 \%$ were aged 50 years and above).

\subsubsection{Marital Status of Respondents}

The data indicated that majority of the respondents from the prisons were not married which was typical of prison population. It therefore suggested that having a spouse helped to stay away from crime. Indeed, people who had strong social ties were less likely to commit crime than those who had weak social ties. Out of the 50 respondents, only $26 \%$ were married whereas the remaining $74 \%$ had no spouse. This confirmed the control theorists' argument that people with strong social bonds are more restrained from committing criminal activities and vice versa (Hirschi, 1969). Among the respondents (public) two-thirds were either married or had married before which meant that they were socially responsible. Within the Ghanaian society, married people are accorded high degree of respect as they are perceived to be mature, deep thinking and befit other positive considerations and that their perceptions about community service can be relied on.

\subsubsection{Academic Attainment}

With regard to level of education, $14 \%$ of the prisoners had had no formal education, $50 \%$ had completed basic/middle school, $32 \%$ had attained secondary/ vocational education and $4 \%$ were educated up to the tertiary level. From the public respondents, seven had no formal education, 29 had been educated up to the basic/middle school level and more than one-third had had up to secondary/vocational level education. About $40.7 \%$ had had tertiary level education. The data indicated that less educated people were more likely to commit crimes than those who were highly educated. The low level of education meant difficulty in obtaining jobs in Ghana where employers looked for certificates and not skills before hiring people. The unavailability of jobs coupled with the absence of social intervention schemes, forced people to adopt deviant means to survive which ended them in prison. Also, the level of education indicated that whatever opinion the community members had about community service and imprisonment was based on informed decision.

\subsubsection{Employment Status}

$62 \%$ of the prison respondents said they were working as part-time/casual labourers before incarceration, $16 \%$ were unemployed, $18 \%$ were in fulltime employment and $2 \%$ were contractors. The data indicated that having a gainful employment was an antidote to committing crime. It could therefore be said that people resorted to crime as a subsistence strategy. Reducing unemployment levels in the country would thus help to reduce crime levels.

\subsubsection{Penal Records}

Penal records of the respondents were collected to be able to assess whether or not imprisonment was helping to reduce re-commission of offence after sentence. The responses indicated that many people returned to prison after their first incarceration. Thus, 34\% answered that it was not their first time in prison whilst $66 \%$ stated that they had never been to prison before. Since prisons were supposed to reform the inmates, $34 \%$ recidivism rate was such a significant figure that the effectiveness of reformatory programmes was questioned. Hence, the purpose of imprisonment was not being achieved which strengthened the need for alternative ways of punishing offenders which may help them to reform.

\subsubsection{Number of Times Serving Prison Term}

The data obtained supports the differential association and learning theorists' argument that deviant behaviour is learnt through interaction with deviant others. The data showed that many people were likely to return to prison after their second term than those who have served only one term. Out of the 17 respondents who said they had been to prison before, two were serving a second term and six were serving a third term or more. The remaining nine were serving a prison sentence for the first time. For the nine, their previous stay in prison was on remand which meant that they were either fined or acquitted by the courts after trial. The fact that six out of the 17 respondents were serving the third time or more in prison confirmed the ineffectiveness of the reformation programmes in prison which meant that the more one was exposed to prison conditions, the more likely he was to return to prison after release due to his inability to reintegrate into the society.

\subsubsection{Length of Previous Stay in Prison}

The data specified that the longer one stayed in prison, the more likely he was to return to prison. This was because more than half of the respondents with previous prison experience had stayed a minimum of one month during their first prison term. The others had stayed between one month and more than 25 months.

\subsubsection{Number of Months Serving}

The data showed that majority of the prisoners (52) were serving more than one year. Since the prisons had not been effective in reforming prisoners, it was worrying that many people were serving more than one year in prison. Given 
that majority of the prisoners were within the active working age group, their incarceration and resources spent on them represented both direct and indirect drain on the country's GDP. It was thus necessary to find alternatives to prison terms that would allow offenders to contribute to the GDP whilst paying for the crime they had committed.

\subsection{Attitude, Experiences and Perception of Inmates towards Prison and Community Services}

\subsubsection{Regret Due to Punishment for Crime Committed}

Contrary to public held opinion that prison had lost its deterring value, and that offenders no longer regretted their crime, the data specified that they actually regretted their crime. Because of the difficulty in reintegrating into the society after imprisonment (Windzio, 2006), very few would want to go back to prison again. Thus, $94 \%$ of the prisoners said that they had regretted the crime they committed because they were severely punished.

\subsubsection{Appropriateness of Punishment to Crime Committed}

On whether the punishment prisoners were serving was commensurate with the crime they committed, the data revealed that significant number of prisoners (98\%) did not consider imprisonment as an appropriate punishment. This explained why many of them were not reformed even after coming out of prison. But more than $50 \%$ of the public asserted that victims were usually satisfied when they found offenders being punished. With community service, the victim was likely to see the offender rendering service or performing a task in the community.

\subsubsection{Preference for Community Service}

To assess respondents' preference for community service in relation to imprisonment, they were required to indicate the level of their willingness to do community service and the type of work they could render. The responses indicated that people generally preferred community service to imprisonment and were more willing to do work that did not require much skills and would be of benefit to the entire society. Thus, $74 \%$ of the prison respondents preferred community service to imprisonment as a form of punishment. The general public seemed to prefer community service as an alternative to imprisonment for minor offences committed by less risky offenders. This was because $56 \%$ indicated that they preferred community service as an alternative to imprisonment.

\subsubsection{Type of Community Service Preferred}

When the respondents (public/prisoners) were requested to select their preferred activities from some preselected activities which could be carried out under community service, the data indicated that they generally preferred to perform tasks which required less skills but are beneficial to the community such as construction of public building, cleaning of public places, cleaning of cemetery/digging of graves, digging of drainage, making of school furniture for public schools, farm work, painting of public buildings, construction of feeder roads, tree planting, sewing uniforms for public school children and crossing of school children on the street.

\subsubsection{Perception about Community Service Relative to Imprisonment}

Among the prisoners, community service was seen as being able to reduce the stigma that was usually attached to ex-convicts than imprisonment. Community service was also perceived by prisoners as being able to offer offenders the opportunity to compensate their victims and the society for the crime they committed better than imprisonment. Consequently, many of them showed their preference for community service instead of imprisonment. However, as argued by the deterrent theorists, community service was perceived to be a more lenient form of punishment than imprisonment. Thus, when the respondents were requested to indicate that 'doing community work would reduce the stigma attached to ex-convicts than imprisonment', the answers specified that prisoners perceived community service to reduce the stigma attached to ex-convicts. Also, about two-thirds of the respondents (general public) agreed that they perceived community service as an effective way of removing the stigma attached to ex-convicts.

\subsubsection{Perception of Community Service as a Lenient Form of Punishment}

The respondents from the prisons indicated that they perceived community service to be a more lenient form of punishment than imprisonment. This was because more than half of the respondents agreed to the statement. This corroborated the deterrence theorists' rejection of community service as being able to help reduce commission of crime. Specifically, 27 respondents perceived community service as a lenient form of punishment. The public generally perceived community service as a lenient form of punishment for deterring the commission of crime. This meant that they validated the assumption that people generally perceived community service as a lenient form of punishment. It confirmed the argument by the deterrent school that since the stigma attached with imprisonment is higher it is more capable of deterring commission of offence than community service. But the high preference for community service was influenced by the fact that it was perceived to be more effective in helping offenders to reintegrate into society than imprisonment. 


\subsubsection{Perception on the Use of Community Service as Compensation for Victims}

In response to a question as to whether community service adequately compensated for victims, $88 \%$ of the prisoners indicated that community service provided better opportunity for offenders to compensate their victims and society than imprisonment. But the public generally disagreed with the statement and indicated that they perceived imprisonment as providing better compensation to offenders than community service. This was, perhaps, due to the stigma that society attached to imprisonment. People felt that if offenders were incarcerated, apart from the harsh prison conditions, they suffered stigmatization and that alone compensated the victims.

\subsection{Public Awareness, Perception, and Recommendation for Community Service}

\subsubsection{Public Awareness about Community Service}

Although community service was not in existence, almost two-thirds $(61 \%)$ of the respondents stated that they were well informed about community service. Given that respondents were generally well informed about community service, it explained that the choices they made between community service and imprisonment were knowledge-based and not out of ignorance. It also meant that the respondents could effectively contribute to any public discourse on the use of community service in place of traditional imprisonment.

\subsubsection{Public Perception of Community Service as a Form of Punishment}

The data obtained showed that people generally had a good perception about community service as a punishment option. They, however, felt that community service was lenient relative to imprisonment. But more than half of the respondents (62\%) disagreed that imprisonment was the most suitable way of punishing offenders because they did not consider the prisons as the most effective means of punishment relative to other punishment options.

\subsubsection{Criteria for Selecting People for Community Service}

The objective was to determine how people should be selected for community service. A number of options were given for respondents to indicate the extent of their agreement.

\subsubsection{Voluntarism}

The respondents were required to indicate their level of agreement to the statement that doing community service must be optional or voluntary rather than the court imposing it on convicts. About half of the respondents (50\%) disagreed with the statement meaning that they preferred community service to be imposed by the courts instead of allowing offenders to decide.

\subsubsection{Categories of People to be allowed to do Community Service}

The respondents were generally influenced by health considerations in their decisions about which category of people should be allowed to do community service. They preferred convicts with communicable diseases to be considered for community service, followed by pregnant women and nursing mothers, first time offenders and single parents.

\subsubsection{Social Integration through Community Service and Imprisonment}

The researchers wanted to find out how respondents would feel toward people doing community service as punishment. This was to assess the likely public reaction to offenders doing community service in their communities if it was introduced. The responses $(60 \%)$ revealed that the public would adopt a friendly reaction to offenders doing community service. This was in conformity with the public's high preference for community service which supported the social integration of offenders.

\subsubsection{Offences to be Made Punishable by Community Service}

In responding to a question on which offences should be made punishable by community service, they generally preferred public disturbance, minor traffic offences and domestic violence which were considered as accidental offences and could be committed by anybody, no matter how law-abiding one may be. Thus, the respondents selected minor fraud, assault and deceit of a public official, minor domestic violence, minor traffic offence and causing minor damage to public property, contempt of court, defilement, incest and public disturbance as offences punishable by community service.

\section{Discussion of Findings}

It was found out that $90 \%$ of the prisoners selected for the study were males and $10 \%$ were females which meant that men were more prone to committing crimes than women. With men being the breadwinners in most families, their incarceration affected the family members, particularly children, to the extent that some ended up becoming deviants. Also, the majority of the prison population was significantly people of the active working age group. Findings also revealed that majority of the respondents from the prisons were not married which is typical of prison population which 
therefore suggested that having a spouse helped to stay away from crime. Conversely, people who had strong social ties were less likely to commit crime than those who had weak social ties. Another finding was that less educated people were more likely to commit crimes than those who were highly educated. The low level of education meant difficulty in obtaining jobs in Ghana where employers look for certificates and not skills before hiring people.

The finding from the study was that the respondents generally preferred community service to imprisonment and were more willing to do work that did not require much skills that would be of benefit to the entire society. Thus, $74 \%$ of the prison respondents preferred community service to imprisonment as a form of punishment whereas $56 \%$ of the general public preferred community service as an alternative to imprisonment for minor offences committed by less risky offenders. The type of community service preferred included construction of public building, cleaning of public places, cleaning of cemetery/digging of graves, digging of drainage, making of school furniture for public schools, farm work, painting of public buildings, construction of feeder roads, tree planting, sewing uniforms for public school children and crossing of school children on the street.

It was found out that community service was able to reduce the stigma that was usually attached to ex-convicts than imprisonment. Also, community service was also perceived by prisoners as being able to offer offenders the opportunity to compensate their victims and the society for the crime they committed better than imprisonment. But the deterrent theorists argued that community service was perceived to be a more lenient form of punishment than imprisonment. Also, they perceived community service to be more effective in removing the stigma attached to conviction and imprisonment. The high preference for community service was influenced by the fact that it was perceived to be more effective in helping offenders to reintegrate into society than imprisonment.

Another finding was that although community service was not in existence, almost two-thirds (61\%) of the respondents were well informed about community service. Because they were well informed about community service, it indicated that the choices they made between community service and imprisonment were knowledge-based which meant that the respondents could effectively contribute to any public discourse on the relevance of community service.

In addition, community service was a preferred alternative to imprisonment, especially for minor offences committed by first time and less dangerous offenders. Also, the general preference for community service was related to the perception of the public regarding community service as the most appropriate form of punishment. But the majority of the respondents (public) disagreed that imprisoning offenders was the best way of punishment because the public perceived community service as offering little deterrent value than imprisonment and the best way of preventing re-offence by deterring would-be offenders was through imprisonment. This finding confirms the deterrence theory's argument that the deterrent effect of community service can be expected to be less strong than the deterrent effect of imprisonment. Therefore, deterrence theory leads to the hypothesis that community service will lead to higher post-sentencing re-offending rates than imprisonment (Windzio, 2006).

Minor fraud, assault, minor domestic violence, minor traffic offence, causing minor damage to public property and public disturbance were found to be the main offences that, according to the public must be performed under community service. The emphasis on minor offences corroborated the research findings of SESR (2007) which revealed that generally, community service is perceived as an appropriate first choice of punishment for minor and non-violent crimes such as vandalism, minor driving offences, shoplifting and car theft. "There is a firm body of opinion that community service should only be used for minor offences" (SESR, 2007). But majority of the respondents (public) indicated people who continuously committed crimes while on community service should either be given a severe punishment or had their days extended.

Another finding was that two main conditions were to be met before community service for an offender was agreed. First of all, respondents insisted that community service should not be voluntarily chosen by the offender but rather must be imposed on the offender. Secondly, specific categories of people who were to be allowed to serve community sentence should include persons with communicable diseases, pregnant women and nursing mothers, single parents and first time offenders.

A key finding was that the types of work such as cleaning of public places, clearing of cemetery or digging graves, serving as a traffic guards on the street and farming were the most common activities that respondents (both prisoners and public) perceived to be necessary for community service activities. These activities appeared communal in nature and of benefit to entire the community. These types of work allowed the offender to perform unpaid services to the community. Thus, they offered an opportunity for reparation and restoration, and at the same time punished the offenders for the crimes they committed (MOJ, 2012). By working with other people in the community, offenders begin to consider the needs of others in their actions, which serves as an important basis for reformation. Unpaid work in the community would help offenders to make amends for the crimes they committed. 


\section{Recommendations}

Given the potential contribution that an effective community service programme can make to the Criminal Justice System in Ghana, the study recommends that it should be made part of the training of the professionals working within the Criminal Justice system. This will help create a knowledgeable human resource base that can form the foundation for the implementation of an effective community service programme in Ghana. In order to clearly define the operational boundaries for community service, it is recommended that the Criminal Justice System provide a clear definition of what constitutes minor offences, and how community sentences may deal with repeated but minor offenders.

It is also recommended that intensive public education be carried out to sensitize the populace about community service before any attempt is made to introduce it in the correction system. The education should include the need for alternative to imprisonment, selection criteria, and the role expected of the society.

The study also recommends that if community service is introduced, offenders must be used to execute tangible programmes like construction of public structures. Such projects will leave lasting impact in the community even years after completion of an offender's period of sentence.

\section{Conclusion}

Public awareness about community service as an alternative to imprisonment in Ghana is high. About $60 \%$ of the population knows about community service and its effectiveness in reforming offenders. The study also revealed that majority of prisoners prefers community service to imprisonment as punishment for criminals. The majority of respondents among the general public also preferred community service to imprisonment for offenders of minor crimes. Preferably, cleaning of public places, clearing of cemetery or digging graves, traffic guards on the street and farming were the most common activities that both categories of respondents recommended for community service. District assemblies should be in charge of finding community work for the people to perform. Supervision should be done by assembly members and unit committees in conjunction with the Ghana Prison Service and the Judicial Service.

\section{References}

Agboka J. Y. G. (2008). Restorative justice: An ethical and practical solution to Ghana's criminal justice system. Retrieved from, www.myjoyonline.com on 17 February 2011.

Akers, R. L. (1997). Deviant behavior: A social learning approach. Belmont: Wadsworth.

Bazemore, G. \& Maloney, D. (1994). 'Rehabilitating community service toward restorative service sanctions in a balanced justice system', Federal Probation, 58(1), 24-35

Becker, G. S. (1963) Outsiders: Studies in the sociology of deviance, New York: Free Press.

Bernburg, J. G., \& Krohn, M. D. (2003) 'Labeling, life chances, and adult crime: The direct and indirect effects of official intervention in adolescence on crime in early adulthood', Criminology, 41(4), 1287-1318. http://dx.doi.org/10.1111/j.1745-9125.2003.tb01020.x

Birungi, C. (2005) Community service in Uganda as an alternative to imprisonment: A Case study of Masaka and Mukono districts, mini-thesis submitted to the Institute for Social Development, Faculty of Arts, University of the Western Cape, in Partial Fulfillment of the Requirement for the MA Degree in Development Studies.

Farrington, D. P. (1977). The effects of public labeling. British Journal of Criminology, 17(2), 112-125

Flick, U. (1998). An introduction to qualitative research. Thousand Oaks, CA: Sage.

Ghana Prison Service, (2007). Ghana Prison Service Annual Report. Accra.

Ghana Prison Service, (2008). Ghana Prison Service Annual Report. Accra.

Ghana Prison Service, (2009). Ghana Prison Service Annual Report. Accra.

Ghana Prison Service, (2010). Ghana Prison Service Annual Report. Accra.

Ghana Prison Service, (2011). Ghana Prison Service Annual Report. Accra.

Ghana Prisons Service (2015). History of Ghana prisons service, viewed on 20 August 2015 at http://www.ghanaprisons.gov.gh/brief.html

Ghana Statistical Service (2010). Population and Housing Census PHC. Ghana

Ghana Statistical Service (2010). Population and Housing Census PHC). Ghana Statistical Service. Accra.

Harris, R. J., \& Lo, T. W. (2002). Community service: Its use in criminal justice. International Journal of Offender Therapy and Comparative Criminology, 46, 427-444.http://dx.doi.org/10.1177/0306624X02464005 
Hirschi, T. (1969). Causes of delinquency, Berkeley: University of California Press.

Klaus, F. J. (1998). Handbook on probation services: Guidelines for probation practitioners and managers. Publication No. 60 Rome/London. Retrieved from: http://www.unicri.it/probation/Probation-handbook.pdf. Accessed on - 07 October 2004.

Künnapas (2005).Community service is an efficient alternative to imprisonment. Retrieved from http://www.just.ee/10119 on 11 August 2009.

Marie-Claude, P., \& Co. (2007).Perceptions of the general public with regard to the correctional service of Canada. Retrieved from Correctional Service Canada Website (www.csc-scc.gc.ca) on 17 July 2011.

Masamba, N. S. (2002). The involvement of (local) communities in crime prevention: The case of African countries. http://www.unicri.it/workshop2002/9-\%20masamba\%20sita.doc Accessed on 2 May 2010.

McAlinden, A. (2005). The use of 'shame' with sexual offenders, British Journal of Criminology, Delinquency and Deviant Social Behaviour, 45, 373-394.

Ministry of Justice (MOJ) United Kingdom (2012). Punishment and reform: effective community sentences, viewed on 24 May 2012 at https://www.gov.uk/government/uploads/system/uploads/attachment_data/file/228573/8334.pdf

Morris, N., \& Tonry, M. (1990). Between prison and probation: Immediate punishments in rational sentencing system, Oxford: University Press.

National Probation Service, (2002). Alternatives to prison. Retrieved on 10 July 2011 from http://www.rethinking.org.uk/informed/pdf/alternatives_to_prison.pdf

Neumann, L. W. (2000). Social research methods: Qualitative and quantitative approaches. New York: Allyn and Bacon.

Penal Reform International (PRI) (2000). Access to Justice in Sub-Saharan Africa. London: PRI. http://www.penalreform.org/english/cs_kadomintro.htm. Accessed on 27 September 2004.

Pettit, B., \& Western, B. (2004). Mass imprisonment and the life course: race and class inequality in U.S. incarceration. American Sociological Review, 69, 151-169.http://dx.doi.org/10.1177/000312240406900201

Pollick, M. (2013). What is public perception? Retrieved from http://www.wisegeek.com/what-is-public-perception.htm Accessed on 15 December, 2013.

Rabie, A. (1977). Theories of punishment, Johannesburg: Perskor Publishers.

Sampson, R. J., \& Laub, J. H. (1995). Crime in the making: pathways and turning points through life. Cambridge: Harvard University Press.

Scottish Executive Social Research (SESR). (2007). Community sentencing: public perceptions and attitudessummary research report, Viewed on 17 May 2012, http://www.gov.scot/resource/doc/203436/0054193.pdf

Stern, V. (1999). Alternatives to prison in developing countries: Some lessons from Africa, Punishment \& Society, 1(2), 231-241. http://dx.doi.org/10.1177/14624749922227801

Stern, V. (2002). Developing alternatives to prisons in Central and Eastern Europe and Central Asia: A guidance handbook. COLPI, Kings College London.

Velazquez, M. \& Lincoln, R. (2009). "What the public thinks about sentencing," The National Legal Eagle, 15(1), Article 3. Retrieved from: http://epublications.bond.edu.au/nle/vol15/iss1/3 on Sun 15 Dec 13.

William A. A. (2007). More ex-convicts return to prison. The Mirror, June $23^{\text {rd }}$. Page 3.

Windzio, M. (2006). Is there a deterrent effect of pains of imprisonment?: The impact of 'social costs' of first incarceration on the hazard rate of recidivism, Punishment \& Society, 8(3), 341-364. http://dx.doi.org/10.1177/1462474506064701

Zedriga, L. W. (1998). Background to community service. A paper presented at the First Regional Sensitisation and Consultation Workshop on the introduction of Community Service in Uganda. Arua Catholic Centre. Uganda.

\section{(cc) $\mathrm{EY}$}

This work is licensed under a Creative Commons Attribution 3.0 License. 